\title{
Pharmacokinetic and Pharmacodynamic Analysis of a Human Immunoglobulin M Monoclonal Antibody in Neonatal Macaca fascicularis
}

\author{
HOWARD V. RAFF, WALT SHUFORD, EDITH WOLFF, AND CRAIG E. RUBENS \\ Infectious Disease Therapy, Oncogen, Seattle, Washington 98121 and the Division of Infectious Disease, \\ Children's Hospital and Medical Center, Seattle, Washington 98105
}

\begin{abstract}
We have developed a human MAb that opsonizes group B streptococci, the major cause of grampositive bacterial sepsis in newborns. It is an IgM class human MAb that possesses unique protective activity against experimental infections caused by the predominant group B capsule serotypes III and I. Preliminary preclinical studies with the IgM human MAb were designed to provide initial information useful for predicting its safety and pharmacokinetic properties. Two neonatal Macaca fascicularis monkeys were infused with the human MAb at either 17.8 or $230 \mathrm{mg} / \mathrm{kg}$. Safety was evaluated by visually monitoring postinfusion clinical status and by standard clinical chemistry analyses and quantitative hematology on blood samples collected for $30 \mathrm{~d}$. The serum antibody levels were determined by ELISA and antibody functional activity in serum samples by opsonophagocytic assays. The IgM human MAb appeared safe (normal laboratory values and clinical status) with a half-life of $2.5 \mathrm{~d}$, a period compatible with the 5-d half-life reported for human IgM in adult serum. In addition, the human MAb retained functional opsonic activity for at least $30 \mathrm{~d}$. Human MAb may offer a safe alternative for treating severe bacterial infections. (Pediatr Res 29: 310-314, 1991)
\end{abstract}

\section{Abbreviations}

GBS, group B streptococci

PK, pharmacokinetic

PD, pharmacodynamics

anti-Id, antiidiotype

Passive immunotherapy with MAb may provide a superior alternative or adjunctive treatment modality to standard antibiotic treatment of bacterial infections. Although several murine antitumor MAb have been administered to humans (1), only one human and one murine MAb, both against the core region of gram-negative bacterial endotoxin, have been similarly tested (2). Despite the recent development and clinical testing of mouse $\mathrm{MAb}$, it is apparent that human MAb offer particular advantages (3), and may be preferred. For example, human MAb should elicit, at most, a minimal host response and possess extended half-lifes. Before MAb of any origin can be considered for clinical use, their safety must be established. The likelihood that human MAb will be safe is supported by extensive clinical experience with i.v. administered human Ig-based formulations. In adults and neonates, these products have not elicited significant negative side effects and therefore appear safe for general use $(4,5)$.

Received July 31, 1990; accepted November 7, 1990.

Reprint requests: Howard V. Raff, Ph.D., Infectious Disease Therapy, Oncogen, 3005 First Avenue, Seattle, WA 98121.
Neonatal infections caused by GBS and Escherichia coli $\mathrm{K} 1$ still have unacceptably high mortality and morbidity rates (6). To supplement current antibiotic therapy, we have developed human MAb with immunotherapeutic potential. Human IgM MAb produced against the group carbohydrate of GBS or the $E$. coli $\mathrm{K} 1$ capsule were found to protect against lethal infections in animal models $(7,8)$. Although administration of human MAb does not have obvious risks, it is still necessary to insure the safety of individual MAb and the methods used for their preparation. Moreover, because these MAb are intended for treatment of infections in neonates, exploring their safety is of paramount importance.

Before initiating formal preclinical safety and PK studies, we performed a preliminary study using two nonhuman primate neonates. The data indicate the GBS MAb is safe without apparent toxicity for the major organ systems or impairment of bone marrow function. Further, in neonatal monkeys the IgM MAb has a half-life of approximately $2.5 \mathrm{~d}$ and maintains commensurate opsonic activity.

\section{MATERIALS AND METHODS}

Animals. Less than 7-d-old male and female monkeys ( $M$. fascicularis) were obtained from and were housed by the Regional Primate Research Center at the University of Washington, Seattle. The animals were housed in individual isolettes in a room designated for newborn monkeys and separated from all other animals. One male (T89001) weighing $550 \mathrm{~g}$ and one female monkey (T89008) weighing $416 \mathrm{~g}$ were administered antibody at $5 \mathrm{~d}$ of age. These particular animals had been rejected by their mothers and were therefore bottle fed before and throughout the study. The Primate Center conforms to the National Institutes of Health Guide for the Care and Use of Laboratory Animals.

Human MAb. A human IgM MAb (4B9) against the group B polysaccharide of GBS was derived by Epstein Barr virus transformation of normal B cells (9). Antibody was purified from nutrient-exhausted culture supernatant by affinity chromatography on a murine antihuman IgM column (7). Concentrated culture supernatant was passed over a Sepharose 4B-murine MAb (Genetic Systems Corp., Seattle, WA) antihuman IgM column (CNBr-activated Sepharose). Bound antibody was eluted with $2 \mathrm{M} \mathrm{MgCl} 2$ in PBS. Purified antibody preparations were dialyzed against $10 \mathrm{mM}$ phosphate in physiologic saline, filter sterilized, and assayed for pyrogen using the Limulus Amebocyte assay QCL-100 (M. A. Bioproducts, Walkersville, MD). Purity was examined by SDS-PAGE of reduced samples followed by silver nitrate staining $(10,11)$. Antibody activity and integrity were determined using an antigen-binding ELISA (8).

Protocol. The antibody was administered via an i.v. catheter placed into an arm vein by percutaneous puncture. The catheter 
was attached to an infusion pump calibrated to deliver the antibody over $15 \mathrm{~min}(0.67 \mathrm{mg} / \mathrm{min}$ for monkey T89001 and $6.67 \mathrm{mg} / \mathrm{min}$ for monkey T89008). To achieve doses of 20 and $200 \mathrm{mg} / \mathrm{kg}$, monkey $T 89001$ received approximately $10 \mathrm{~mL}$ of $\mathrm{MAb}$ at $1.0 \mathrm{mg} / \mathrm{mL}$, and monkey T89008 approximately $13 \mathrm{~mL}$ of MAb at $7.7 \mathrm{mg} / \mathrm{mL}$, respectively. Based on their weights shortly before injection, the actual antibody doses administered to the monkeys were $17.8 \mathrm{mg} / \mathrm{kg}$ (monkey T89001) and 230 $\mathrm{mg} / \mathrm{kg}$ (monkey T89008). Blood samples drawn from the femoral artery provided serum for $\mathrm{PK}$ and functional opsonic assays $(0.5$ $\mathrm{mL}$, no anticoagulant), and plasma and white blood cells for safety studies ( $1.0 \mathrm{~mL}$ in citrate). Samples for PK determinations were obtained according to the following schedule: before injection, at 5, 15, 30, and $60 \mathrm{~min}$, at 6 , and $24 \mathrm{~h}$, and then at 2,3 , $4,7,11,15,20,25$, and $30 \mathrm{~d}$. These samples were clotted on ice for $2-3 \mathrm{~h}$ and the serum collected after centrifugation, divided into three aliquots, and frozen at $-70^{\circ} \mathrm{C}$. Blood for safety determinations was obtained before injection and at approximately $7,15,25$, and $30 \mathrm{~d}$ for clinical chemistry and at 15 and $30 \mathrm{~d}$ for hematology analyses. Quantitative hematology (total white blood cells and differentials) was performed at the Regional Primate Center and clinical chemistry analyses at the Children's Hospital and Medical Center (Seattle, WA) clinical chemistry laboratory.

$P K$ assay. A PK assay was developed using a MAb anti-Id ELISA-based capture format. An antihuman MAb 4B9 idiotypespecific murine MAb was produced by fusing spleen cells from $\mathrm{Balb} / \mathrm{C}$ mice immunized with the human $\mathrm{MAb}$ to murine myeloma cells $(\mathrm{P} 3 \mathrm{X} 63 \mathrm{Ag} 8,12)$. The anti-Id used in the PK assays reacted only with the immunizing IgM antibody, and not other human IgM MAb or the IgM fraction of pooled normal human serum (ICN ImmunoBiologicals, Lisle, IL), suggesting that this anti-Id did not detect a cross-reactive idiotypic determinant present in other human antibodies. The multivalency of the IgM $\mathrm{MAb}$ was exploited by using one anti-Id MAb as both the plasticbound capture antibody and the fluid-phase biotinylated signal source. For the assay, microtiter plate wells were coated overnight at $4^{\circ} \mathrm{C}$ with $100 \mu \mathrm{L}$ of anti-Id $\left(8 \mathrm{~F} 2, \mathrm{IgG}_{2 \mathrm{a}}\right)$ at $2.0 \mu \mathrm{g} / \mathrm{mL}$ in carbonate-bicarbonate buffer. After washing and blocking (5\% nonfat dry milk solution in $0.02 \%$ Tween/PBS) diluted control and serum samples were added to the wells followed by incubation at room temperature for $60 \mathrm{~min}$. After an additional wash step, microtiter wells received biotinylated anti-Id (100 $\mu \mathrm{L} /$ well) for $45 \mathrm{~min}$ at room temperature, were washed, and were treated with Vectastain (Vector Labs, Burlingame, CA) for an additional $20 \mathrm{~min}$ (13). After washing and substrate addition, the assay was completed as previously described. Antibody half-life was calculated from the PK assay data using a computer software program (PKCALC, 14).

Opsonophagocytic assay. The functional activity or "pharmacodynamics" of the antibody in serum samples was quantitated

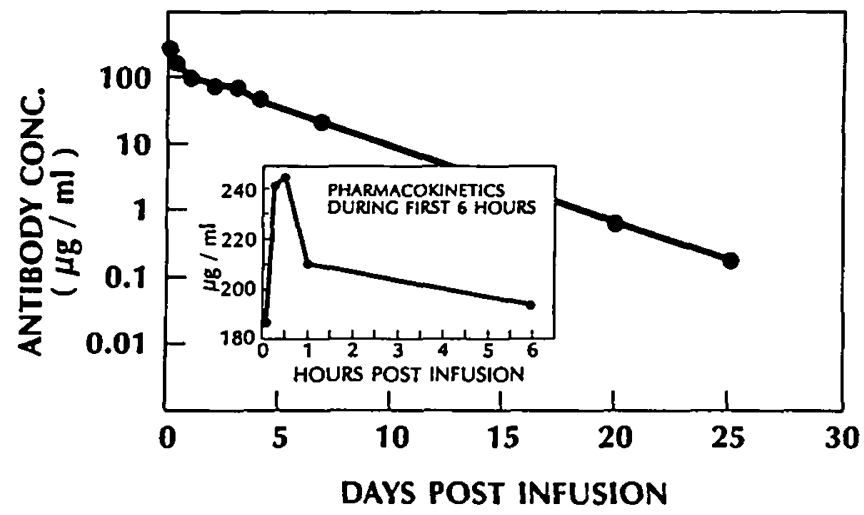

Fig. 1. PK activity of a human MAb $(17.8 \mathrm{mg} / \mathrm{kg})$ administered to a neonatal monkey. Insert depicts antibody PK during first $6 \mathrm{~h}$ postinjection. Human MAb concentrations were determined using an anti-Id MAb capture ELISA. following a protocol described previously (8). MAb-mediated opsonic activity in monkey T89008 serum samples was assayed against two GBS (capsule serotype III) clinical isolates (COH 1 and type IIIR, provided by Drs. C. Rubens and H. Hill, University of Utah School of Medicine, Salt Lake City, UT, respectively, $(15,16)$. Serum samples were diluted $1: 1000$ in PBS to dilute out opsonic activity detected in prebleed sample. For the assay, duplicate tubes were prepared containing in $500 \mu \mathrm{L} 250 \mu \mathrm{L}$ of diluted serum or MAb, $50 \mu \mathrm{L}$ of freshly isolated human neutrophils $\left(5 \times 10^{7} / \mathrm{mL}\right), 75 \mu \mathrm{L}$ human serum as a complement source, $100 \mu \mathrm{L}$ of the GBS strains $\left(4 \times 10^{2} \mathrm{CFU} / \mathrm{mL}\right)$, and 25 $\mu \mathrm{L}$ of Hanks' Balanced salt solution containing $10 \mathrm{mM} \mathrm{N}-2$ hydroxyethylpiperazine- $N^{\prime}$-2-ethanesulfonic acid and $0.1 \%$ gelatin. The bacteria were first incubated with antibody or serum for $30 \mathrm{~min}$ at $37^{\circ} \mathrm{C}$, followed by the addition of the other assay components. The entire mixture was rotated for $60 \mathrm{~min}$ at $37^{\circ} \mathrm{C}$. Negative controls were prebleed serum samples for postinjection serum samples and reaction mixtures lacking complement (heatinactivated FCS substituted for complement) for MAb experiments. In other experiments (data not shown), substituting a negative control human MAb, omitting the neutrophils, or omitting the complement all gave very similar negative control values. Therefore, in these experiments, only the complement control was used. For the serum samples and the MAb, the data are reported as follows: $100 \times[1-(\mathrm{CFU}$ remaining after incubation with neutrophils, complement, and postinjection serum sam-

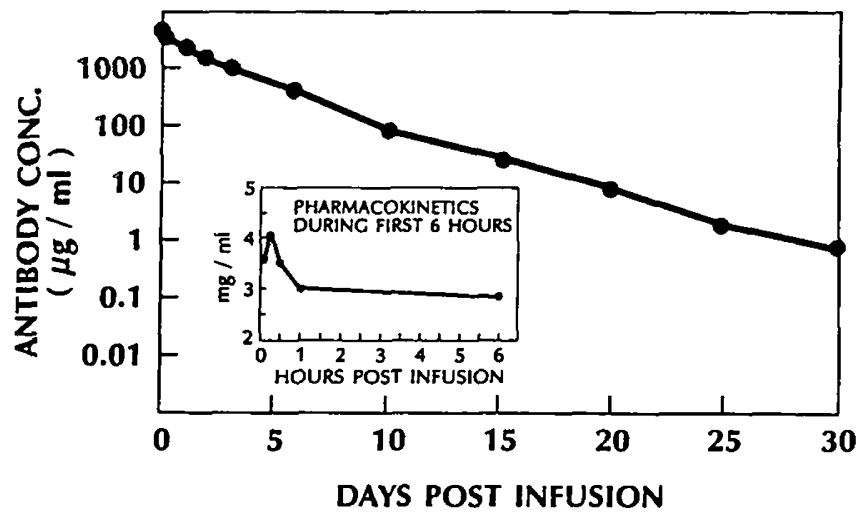

Fig. 2. PK activity of a human MAb $(230 \mathrm{mg} / \mathrm{kg})$ administered to a neonatal monkey. Insert depicts antibody PK during first $6 \mathrm{~h}$ postinjection. Human MAb concentrations were determined as described in Figure 1.

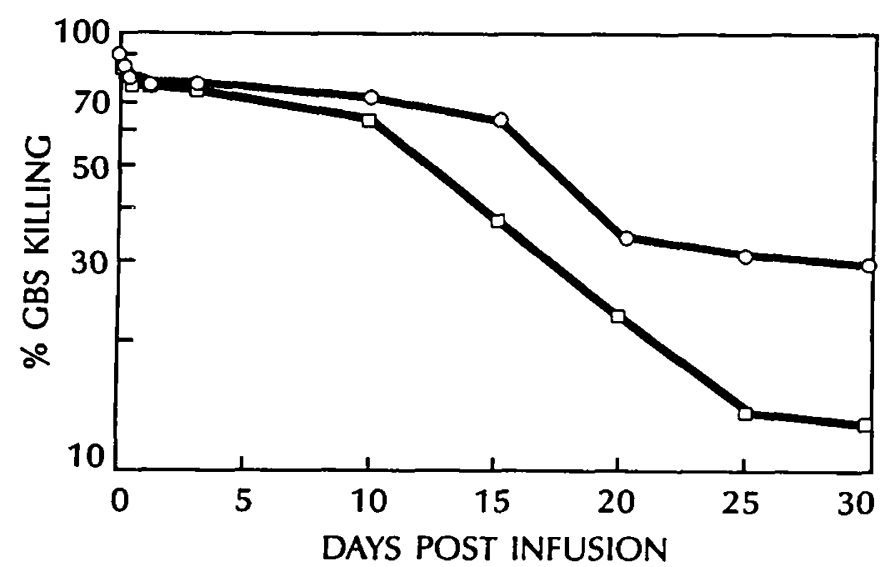

Fig. 3. PK activity of human MAb administered to neonatal monkey. Sera from $\mathrm{T} 89008$ monkey $(230 \mathrm{mg} / \mathrm{kg})$ were tested for complementdependent opsonic activity against two capsule serotypes III human neonatal clinical isolates ( $\mathrm{COH} 1$, open circles; type IIIR, open squares). All serum samples were diluted 1:1000 for the assay and combined with human neutrophils and complement. 


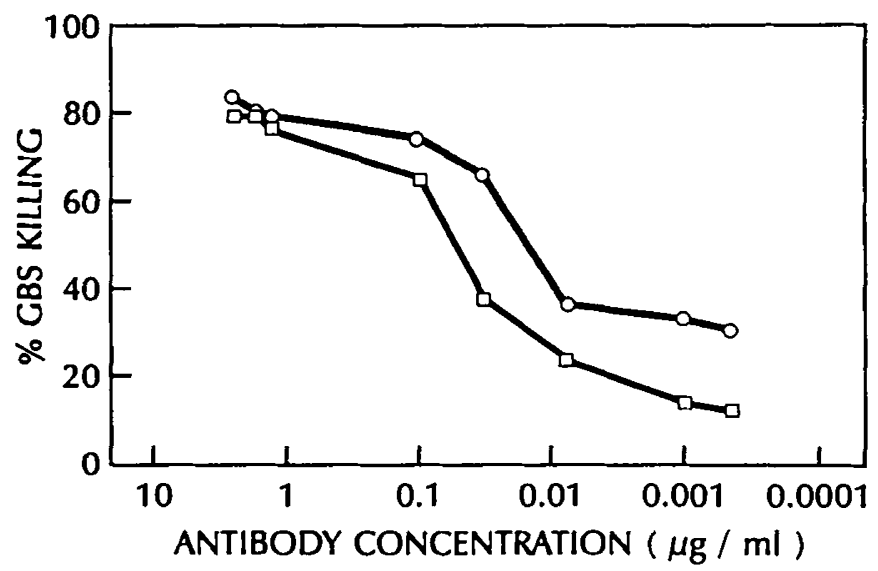

Fig. 4. Opsonophagocytic activity of human MAb administered to neonatal monkeys. Human MAb 4B9 was titrated in an opsonophagocytic assay against two clinical isolates $(\mathrm{COH} 1$, open circles; type IIIR, open squares).

ples)/(CFU remaining after incubation with neutrophils, complement, and prebleed serum)] or $100 \times[1-(\mathrm{CFU}$ remaining after incubation with neutrophils, complement, and MAb)/(CFU remaining after incubation with neutrophils, FCS, and MAb)].

\section{RESULTS}

$P K$. Affinity column purified antibody was shown by SDSPAGE to be essentially free of protein contaminants (data not shown) and to contain $0.26 \mathrm{ng}$ endotoxin/8.5 mg MAb (30 pg/ $\mathrm{mg})$. Five-d-old cynomolgous ( $M$. fascicularis) monkeys were injected i.v. with either 17.8 (T89001) or $230 \mathrm{mg} / \mathrm{kg}$ (T89008) of MAb 4B9. Blood samples were drawn starting 5 min after infusion for $30 \mathrm{~d}$. The MAb concentration in serum was quantitated using an anti-Id-based capture ELISA. Because IgM antibodies are multivalent, it was found that the same murine antiId MAb could function as both the capture antibody and the signal antibody (biotinylated). By limiting the capture antibody, the idiotopes on each 4B9 IgM molecule were not saturated, thereby allowing signal anti-Id MAb to bind the same IgM molecules. The assay is sensitive to $1 \mathrm{ng} \mathrm{MAb} / \mathrm{mL}$ and is not affected by $<10 \%$ monkey or human serum.

Using this assay, it appeared that in high and low dose monkeys the human MAb was affected by an initial 6-h clearance and equilibration phase where the antibody concentration fell by 30 $40 \%$ (Figs. 1 and 2, insets) followed by a more prolonged, gradual decrease. From these studies, it was shown that the human MAb had a 2.5-d half-life in monkey T89001 (Fig. 1) and a 2.4 d halflife in monkey T89008 (Fig. 2).

Opsonic activity. Although the physical presence of antibody was detected in serum by the PK assay, an equally important question is whether the antibody retains opsonic or functional activity during this time. Antibody opsonic activity was quantitated in the serum samples obtained from monkey T89008. Serum from each time point was diluted 1:1000 and used in opsonic assays against two serotype III GBS clinical isolates (COH 1 and type IIIR). The data show that the pharmacodynamics of the MAb differ depending on the clinical isolate (Fig. 3). Strain $\mathrm{COH} 1$ appears to require less antibody to be effectively opsonized than does strain type IIIR. This observation is reflected in control opsonization experiments when the same antibody administered to the monkeys was tested against these strains (Fig. 4). Approximately four times more MAb was necessary to provide $50 \%$ of the maximal opsonic activity ( $80 \%$ killing) against strain type IIIR than was required against strain $\mathrm{COH} 1(80$ versus $20 \mathrm{ng} / \mathrm{mL}$, respectively). Because the relative opsonic activity of control and in vivo circulating MAb was the same, these data suggest that the physical detection of the MAb (PK) is reflected by its functional opsonic activity.

Safety parameters. The safety of the MAb was assessed by observing clinical signs after injection and by monitoring a number of clinical chemistry and hematology parameters. During and after MAb administration the monkeys did not demonstrate any behavioral changes that would suggest discomfort, pain, or trauma. Their general activity and feeding levels remained unchanged throughout the study. Blood samples for these studies were obtained before injection and then at approximately 7- or 15-d intervals. Values for kidney function (creatinine and blood urea nitrogen) and liver enzymes (serum glutamic oxaloacetic transaminase and serum glutamic pyruvic transaminase) were within normal limits throughout the study, except for the prebleed and 7-d bleed for monkey T89001, which had slightly elevated SGOT levels due to hemolysis of the sample (Table 1). Extensive evaluation of hematology parameters also shows that there was little fluctuation from the prebleed values, suggesting the MAb did not adversely affect circulating cells or bone marrow function (Table 2).

Table 1. Serum chemistries of newborn monkeys receiving human MAb*

\begin{tabular}{|c|c|c|c|c|c|}
\hline \multirow[b]{2}{*}{ Monkey } & \multirow[b]{2}{*}{$\begin{array}{c}\text { Days } \\
\text { postinfusion }\end{array}$} & \multicolumn{4}{|c|}{ Assays } \\
\hline & & $\begin{array}{c}\text { BUN } \\
(\mathrm{mg} / \mathrm{dL}) \\
(8-26) \dagger\end{array}$ & $\begin{array}{c}\text { Creatinine } \\
(\mathrm{mg} / \mathrm{dL}) \\
(0.7-1.5) \dagger\end{array}$ & $\begin{array}{l}\text { SGOT } \\
(\mathrm{IU} / \mathrm{L}) \\
(8-74) \dagger \\
\end{array}$ & $\begin{array}{c}\text { SGPT } \\
\text { (IU/L) } \\
(5-60) \dagger \\
\end{array}$ \\
\hline \multirow[t]{5}{*}{ T89001‡ } & Preinjection & 4 & 0.7 & 128 & 13 \\
\hline & $7 \S$ & 4 & 0.6 & 99 & $<3$ \\
\hline & $15^{\circ}$ & 6 & 0.4 & 47 & 11 \\
\hline & 25 & 6 & 0.3 & 38 & 8 \\
\hline & 30 & 7 & 0.4 & 38 & 19 \\
\hline \multirow[t]{5}{*}{ T89008\| } & Preinjection & $<2$ & 0.6 & 50 & 25 \\
\hline & 11 & 2 & 0.4 & 49 & 3 \\
\hline & 15 & 4 & 0.3 & 40 & 6 \\
\hline & 25 & 5 & 0.3 & 19 & 12 \\
\hline & 29 & 13 & 0.3 & 33 & 19 \\
\hline
\end{tabular}

* BUN, blood urea nitrogen; SGOT, serum glutamic oxaloacetic transaminase; SGPT, serum glutamic pyruvic transaminase.

† Normal range for newborn monkey.

$\ddagger$ Low-dose monkey $(20 \mathrm{mg} / \mathrm{kg})$.

$\S$ Hemolyzed sample.

|| High-dose monkey $(200 \mathrm{mg} / \mathrm{kg})$. 
Table 2. Quantitative hematologic evaluation of newborn monkeys receiving human $M A b$

\begin{tabular}{|c|c|c|c|c|c|c|}
\hline \multirow[b]{2}{*}{ Test } & \multicolumn{3}{|c|}{$\begin{array}{l}\text { T89001 (d post- } \\
\text { infusion) }\end{array}$} & \multicolumn{3}{|c|}{$\begin{array}{l}\text { T89008 (d post- } \\
\text { infusion) }\end{array}$} \\
\hline & Pre & 15 & 30 & Pre & 15 & 30 \\
\hline $\mathrm{Hb}(\mathrm{g} \%)$ & 15.4 & 12.2 & 14.6 & 12.0 & 12.6 & 12.0 \\
\hline Hematocrit (vol\%) & 46.8 & 38.7 & 45.0 & 37.5 & 40.2 & 43.5 \\
\hline $\begin{array}{l}\text { Red blood cell count } \\
\left(\times 10^{6} / \mathrm{mm}^{3}\right)\end{array}$ & 6.4 & 5.6 & 5.7 & 5.0 & 5.4 & 5.2 \\
\hline $\begin{array}{l}\text { Mean corpuscular } \mathrm{Hb} \\
(\mu \mu \mathrm{g})\end{array}$ & 24.1 & 21.9 & 23.0 & 24.0 & 23.2 & 24.0 \\
\hline Mean corpuscular vol $\left(\mu^{3}\right)$ & 74 & 71 & 71 & 76 & 75 & 72 \\
\hline Platelet count & $\mathrm{Nm}^{*}$ & $\mathrm{Nm}$ & $\mathrm{Nm}$ & $\mathrm{Nm}$ & $\mathrm{Nm}$ & $\mathrm{Nm}$ \\
\hline Capillary clot time & $\mathrm{Nm}$ & $\mathrm{Nm}$ & $\mathrm{Nm}$ & $\mathrm{Nm}$ & $\mathrm{Nm}$ & $\mathrm{Nm}$ \\
\hline $\begin{array}{l}\text { White blood cell count } \\
\left(\times 10^{3} / \mathrm{mm}^{3}\right)\end{array}$ & 8.2 & 7.9 & 8.1 & 8.3 & 6.8 & 7.3 \\
\hline Neutrophils & 33 & 20 & 27 & 33 & 38 & 35 \\
\hline Lymphocytes & 67 & 78 & 73 & 62 & 59 & 65 \\
\hline Monocytes & 0 & 2 & 0 & 2 & 2 & 0 \\
\hline Eosinophils & 0 & 0 & 0 & 3 & 1 & 0 \\
\hline $\begin{array}{l}\text { Red blood cell } \\
\text { morphology }\end{array}$ & $\mathrm{Nm}$ & $\mathrm{Nm}$ & $\mathrm{Nm}$ & $\mathrm{Nm}$ & $\mathrm{Nm}$ & $\mathrm{Nm}$ \\
\hline
\end{tabular}

${ }^{*} \mathrm{Nm}$, within normal limits.

\section{DISCUSSION}

These studies report the first safety and half-life data in which neonatal monkeys were administered a human IgM MAb. Two 5-d-old cynomolgous ( $M$. fascicularis) monkeys were infused with either 17.8 or $230 \mathrm{mg} / \mathrm{kg}$ of an anti-GBS HuMAb. Both doses were well tolerated based on clinical observation and safety parameters. No apparent changes from prebleed values occurred in serum levels of liver transaminases, in serum creatinine clearance by the kidneys, or in hematologic parameters. The circulating half-life of the MAb was directly quantified using an anti-Id capture ELISA was found to be approximately $2.5 \mathrm{~d}$ regardless of the antibody dosage. The integrity and activity of antibody $\mathrm{Fc}$ regions was not determined by the anti-Id assay. To explore whether the IgM MAb retained functional activity, the same monkey serum samples were tested for opsonic activity in an in vitro assay. Our results show that after $30 \mathrm{~d}$ of in vivo circulation the antibody still maintains opsonic activity. Moreover, in control experiments comparing the same MAb administered to the monkeys with MAb in the serum samples, it was shown that they both had similar relative activities against the two GBS clinical isolates, further suggesting the antibody was stable after long-term in vivo passage.

One particular focus of these studies was the half-life of an IgM MAb in neonatal monkeys. At birth there is little or no IgM present in the neonate because IgM antibodies are not transplacentally passed to the fetus. Therefore, the only data on the half-life of human IgM antibodies are from studies in juveniles and adults, indicating that the average half-life of IgM antibodies is approximately $5 \mathrm{~d}(17)$. The finding that the GBS MAb has a half-life of approximately $2.5 \mathrm{~d}$ in cynomolgous monkeys is encouraging, and leads us to anticipate that the half-life will be no less in human neonates. A 2- to 3-d half-life should avoid the need for a particularly high antibody dosage to maintain a clinically efficacious concentration of circulating antibody.

The half-life directly relates to predicting the dosage necessary to manifest clinical efficacy. An average anticipated dosage of 20 $\mathrm{mg} / \mathrm{kg}$ in human neonates is based on body weight extrapolations from studies in a neonatal rat infection model (8). This dosage was administered to monkey T89001 $(17.8 \mathrm{mg} / \mathrm{kg})$ and approximately 10 times this amount to monkey T89008 $(230 \mathrm{mg} / \mathrm{kg})$. Based on data obtained from opsonophagocytic experiments performed with serum from the high-dose monkey and MAb from the same lot, it seems likely that even in the monkey receiving $17.8 \mathrm{mg} / \mathrm{kg}$, an adequate concentration of $\mathrm{MAb}$ remained after $25 \mathrm{~d}$ to opsonize even the more resistant GBS strain (type IIIR).

Because human MAb have not previously been administered to neonatal monkeys or humans, the only relevant safety studies are with i.v. Ig products intended for use in preventing and/or treating neonatal bacterial infections. Studies in human neonates have shown that doses up to $750 \mathrm{mg} / \mathrm{kg}$ are safe in this patient population, and preliminary studies indicate that these products may possess antiinfective potential $(5,18)$. The safety in neonates of a formulation containing $12 \% \mathrm{IgM} \mathrm{Ig}$ by weight has also been shown (19). However, the use of i.v. Ig formulations may not be without its risks. To maintain elevated serum levels of anti-GBS antibodies, administration of $500 \mathrm{mg} / \mathrm{kg}$ i.v. Ig was required (5). At this dosage, the possibility arises of increasing the catabolic rate of $\mathrm{IgG}$ and perhaps reducing IgG titers of specific opsonic antibodies (20). In addition, in experimental GBS infection studies, high doses of i.v. Ig administered alone (21) or in conjunction with antibiotics resulted in less therapeutic efficacy compared with control treatments (22). These studies suggest that high doses of i.v. Ig may cause phagocytic cell receptor blockade or other immunoinhibitory activity. By using substantially smaller doses of human MAb, we hope to avoid these potential problems and gain the advantage of administering standardized dosages of opsonic antibodies.

We began this effort by administering one human IgM MAb to healthy, neonatal nonhuman primates. The apparent safety of this human IgM in neonatal monkeys encouraged us to proceed with developing the anti-GBS MAb for additional preclinical safety and PK studies.

\section{REFERENCES}

I. Wettenforff M, Iliopoulos D, Tempero M, Kay D, DeFreitas E, Koprowski H, Herlyn D 1989 Idiotypic cascades in cancer patients treated with monoclonal antibody CO17-1A. Proc Natl Acad Sci USA 86:3787-3791

2. Harkonen S, Scannon P, Mischak R, Spitler L, Foxall C, Kennedy D, Greenberg R 1988 Phase I study of a murine monoclonal anti-lipid A antibody in bacteremic and nonbacteremic patients. Antimicrob Agents Chemother $32: 710-716$

3. Glassy M, Dillman R 1988 Molecular biotherapy with human monoclonal antibodies. Mol Biother 1:7-12

4. Fischer G, Weisman L, Hemming B, London W, Hunter D, Bosworth J 1984 Intravenous immunoglobulin in neonatal group $b$ streptococcal disease. Pharmacokinetic and safety studies in monkeys and humans. Am J Med 75:117-123

5. Chirico G, Rondini G, Plebani A, Chiara A, Massa M, Ugazio A 1987 Intravenous gamma globulin therapy for prophylaxis of infection in highrisk neonates. J Peds 110:437-442

6. Baker C 1986 Group B streptococcal infections in newborns. N Engl J Med 314:1702-1705

7. Raff H, Devereux D, Shuford W, Abbott-Brown D, Maloney G 1988 Human monoclonal antibody with protective activity against $E . c o l i \mathrm{~K} 1$ and Neisseria meningitidis group B infection. J Infect Dis 157:118-125

8. Raff H, Siscoe P, Wolff E, Maloney G, Shuford W 1988 Human monoclonal antibodies to group B Streptococcus: reactivity and in vivo protection against multiple serotypes. J Exptl Med [988:905-917

9. Siadak A, Lostrom M 1985 Cell driven viral transformation. In: EG Engleman, SKH Foung, J Larrick, A Raubitschek (eds) Human Hybridomas and Monoclonal Antibodies. Plenum Publishing, New York, pp 167-185

10. Haekeshoven J, Dernick R 1985 Simplified method for silver staining of proteins in polyacrylamide gels and the mechanism of silver staining. Electrophoresis 6:103-108

11. Laemmli U 1970 Cleavage of structural proteins during the assembly of the head of bacteriophage T4. Nature 227:680-683

12. Kolher G, Milstein C 1975 Continuous cultures of fused cells secreting antibody of predefined specificity. Nature 256:495-497

13. Shively J, Wagener C, Clark B 1986 Solution-phase RIA and solid-phase EIA using avidin-biotin systems for analysis of monoclonal antibody epitopes and affinity constants. Meths Enzymol 121:459-472

14. Shumaker R 1986 PKCALC: a BASIC interactive computer program for statistical and pharmacokinetic analysis of data. Drug Metab Rev 17:331348

15. Bohnsack J, Hawley M, Pritchard D, Egan M, Shigeoka A, Hill H 1989 An 
IgA monoclonal antibody directed against type III antigen on group b Streptococci acts as an opsonin. J Immunol 143:3338-3342

16. Martin J, Rubens C, Wilson C 1988 Lung anti-bacterial defense mechanisms in infants and adult rats: implications for group B streptococcal infections of neonatal lungs. J Infect Dis 157:91-97

17. Jeske D, Capra J 1984 Immunoglobulins: structure and function. In: W Pau (ed) Fundamental Immunology, Raven Press, New York, pp 131-166

18. Hill H, Shigeoka A, Gonzales L, Christensen R 1989 Intravenous immune globulin use in newborns. J Allergy Clin Immunol 84:617-624
19. Haque $\mathrm{K}$, Zaidi M, Bahakim H 1988 IgM-enriched intravenous immunoglobulin therapy in neonatal sepsis. Am J Dis Child 142:1293-1296

20. Christensen K, Christensen P 1986 Intravenous gamma-globulin in the treatment of neonatal sepsis with special reference to group B Streptococci and pharmacokinetics. Pediatr Infect Dis 5:S189-S192

21. Weisman L, Lorenzetti P 1989 High intravenous doses of human immune globulin suppress neonatal group B Streptococcal immunity in rats. J Pediatr 115:445-450

22. Kim K 1989 Hi-dose intravenous immune globulin impairs antibacterial activity of antibiotics. J Allergy Clin Immunol 84:579-588

\section{Announcement}

\section{Annual Meetings}

The American Pediatric Society, The Society for Pediatric Research, and The Ambulatory Pediatric Association will hold their annual meetings April 28-May 2, 1991 at the New Orleans Hilton and Rivergate Convention Center, New Orleans, LA. For further information contact: APS/SPR Association Headquarters, 2650 Yale Blvd., S.E., Suite 104, Albuquerque, NM 87106, (505)764-9099, FAX (505)842-8227 or Ambulatory Pediatric Association, 6728 Old McLean Village, McLean, VA 22101, (703)556-9222. 